\title{
Impact of Plant-Associated Bacteria on the In Vitro Growth and Pathogenic Resistance against Phellinus tremulae of Different Aspen (Populus) Genotypes
}

\author{
Greta Striganavičiūtė, Jonas Žiauka, Vaida Sirgedaitė-Šèžienė * (1) and Dorotèja Vaitiekūnaitè
}

check for updates

Citation: Striganavičiūtè, G.; Žiauka, J.; Sirgedaitè-Šėžienè, V.;

Vaitiekūnaitè, D. Impact of Plant-Associated Bacteria on the In Vitro Growth and Pathogenic Resistance against Phellinus tremulae of Different Aspen (Populus) Genotypes. Microorganisms 2021, 9, 1901. https://doi.org/10.3390/ microorganisms 9091901

Academic Editor: Stefania Tegli

Received: 20 July 2021

Accepted: 3 September 2021

Published: 7 September 2021

Publisher's Note: MDPI stays neutral with regard to jurisdictional claims in published maps and institutional affiliations.

Copyright: (C) 2021 by the authors. Licensee MDPI, Basel, Switzerland. This article is an open access article distributed under the terms and conditions of the Creative Commons Attribution (CC BY) license (https:/ / creativecommons.org/licenses/by/ $4.0 /)$.
Laboratory of Forest Plant Biotechnology, Institute of Forestry, Lithuanian Research Centre for Agriculture and Forestry, Liepu str. 1, Girionys, LT-53101 Kaunas, Lithuania; gretastrig6@gmail.com (G.S.); jonas.ziauka@lammc.lt (J.Ž.); doroteja.vaitiekunaite@lammc.lt (D.V.)

* Correspondence: vaida.seziene@lammc.lt

Abstract: Aspens (Populus tremula and its hybrids), economically and ecologically important fastgrowing trees, are often damaged by Phellinus tremulae, a rot-causing fungus. Plant-associated bacteria can be used to increase plant growth and resistance; however, no systematic studies relating the activity of symbiotic bacteria to aspen resistance against Phellinus tremulae have been conducted so far. The present pioneer study investigated the responses of two Populus tremula and two P. tremula $\times$ P. tremuloides genotypes to in vitro inoculations with, first, either Pseudomonas sp. or Paenibacillus sp. bacteria (isolated originally from hybrid aspen tissue cultures and being most closely related to Pseudomonas oryzihabitans and Paenibacillus tundrae, respectively) and, in the subsequent stage, with Phellinus tremulae. Both morphological parameters of in vitro-grown plants and biochemical content of their leaves, including photosynthesis pigments and secondary metabolites, were analyzed. It was found that both Populus tremula $\times$ P. tremuloides genotypes, whose development in vitro was significantly damaged by Phellinus tremulae, were characterized by certain responses to the studied bacteria: decreased shoot development by both Paenibacillus sp. and Pseudomonas sp. and increased phenol content by Pseudomonas sp. In turn, these responses were lacking in both Populus tremula genotypes that showed in vitro resistance to the fungus. Moreover, these genotypes showed positive long-term growth responses to bacterial inoculation, even synergistic with the subsequent fungal inoculation. Hence, the studied bacteria were demonstrated as a potential tool for the improved in vitro propagation of fungus-resistant aspen genotypes.

Keywords: Pseudomonas; Paenibacillus; Populus tremula; Populus tremuloides; secondary metabolites; Phellinus tremulae; hybrid poplar; phenols; flavonoids; carotenoids; chlorophyll

\section{Introduction}

Forest trees and their wood quality are threatened by pathogenic fungi [1,2]; thus, one of the most pressing problems in forestry, today, is the selection of tree genotypes for increased growth and better resistance to phytopathogens [3,4]. Therefore, more attention has recently been paid to potentially beneficial interactions between symbiotic bacteria and woody plants.

Endophytic bacteria can promote resistance to stress and pathogens, at the same time stimulating nutritional processes in their hosts, hence affecting overall growth [5-8]. Plant microorganisms can benefit their hosts through a variety of mechanisms, including biological nitrogen fixation and increased bioavailability of phosphorus $(\mathrm{P})$, iron $(\mathrm{Fe})$ and other mineral nutrients, as well as production of plant hormones and various antimicrobial biocontrol compounds [7,9-11]. Plant growth promoting bacteria are being more widely used in agriculture, as an eco-friendly alternative to chemical fertilizers and pesticides [7,12]; however, the potential application of such beneficial bacteria in forestry has not yet been sufficiently explored [13]. 
Tree resistance to pathogens is related to the general viability of trees and their ability to synthesize and mobilize secondary metabolites (SMs) [4,14-17]. Modern technologies for the improvement of forest tree planting material include quantitation of phenolic compounds, since these SMs perform numerous protective functions and their amount is related to general or specific plant pathogenic resistance $[4,14,18,19]$. Endophytic bacteria were proven to have an effect on plants' secondary metabolism [16,20,21]; however, overall, little is known about the mechanisms of how this happens [16]. Moreover, studies show that the ability of different plant genotypes to synthesize SMs and mobilize them against pathogens is variable; therefore, genetic selection is appropriate in this respect $[4,14,15,18]$.

Eurasian aspen (Populus tremula L.) are common pioneer trees in the Northern Hemisphere [15,22-26]. Furthermore, aspen and its hybrids are extensively grown for various commercial enterprises $[14,15,25,27,28]$, as well as being used as a model species for not only woody plant experiments [28], but also plant-microbe interaction studies [29]. Even so, aspen trees suffer from fungal pathogens throughout their habitat range [15,30,31].

According to the data of the State Forest Service, aspens are the most vulnerable in Lithuanian forests. Data show that, in 2020,13\% of the total forest trees was damaged by diseases and $47.7 \%$ of them suffered from pathogen-Phellinus tremulae [32]. P. tremulae is a pathogenic fungus that is associated with aspen rot [14,33]. Several authors have identified it as one of the main pathogens affecting this genus [23,24,33-36], with some stating that up to $39 \%$ of trees may be infected in some areas [22], causing significant yield losses [34,35]. Despite the widespread nature of this pathogenic fungus, little research has been conducted on the antagonistic effects other microorganisms may have on this species. So far as we were able to determine, no systematic studies concerning the impact of different symbiotic bacteria on the formation of pathogenic resistance via SM production in Populus sp. have been conducted yet.

This paper highlights the ability of symbiotic bacteria belonging to the genera Paenibacillus and Pseudomonas to regulate morphogenetic processes and activate the synthesis of protective SMs in different aspen genotypes against phytopathogen $P$. tremulae. This pioneer study evaluates the possibilities of using plant growth promoting bacteria to improve growth, quality and resistance of forest planting material.

\section{Materials and Methods}

\subsection{Populus Genotypes}

Two aspen, Populus tremula (A-37 and R-38), and two hybrid aspen, P. tremula $\times$ P. tremuloides (174/10 and Wa13), genotypes were selected for the study. These genotypes were established in the laboratory of LRCAF Institute of Forestry (Lithuania) in 2017 and kept in vitro for two years via a series of bimonthly subcultures, before being used for the experiments described in this study.

\subsection{Microorganisms}

Two different strains of bacteria were used. Both were isolated from aspen in vitro cultures, that showed no initial external bacterial growth. Bacterial colonies were observed at the base of the microshoots, as well as on the surface of the medium surrounding the microshoot stems, after several bimonthly aseptic transfers. They appeared to be causing no harm to the plants; thus, based on their origin, were determined to be potentially endophytic. Subsequently, samples were taken for genetic testing. DNA extraction and, later, $16 S$ rRNA gene sequencing (universal 27F/800R-518F/1492R primer set) were conducted at the Macrogen sequencing center, Amsterdam, The Netherlands.

In vitro cultures of fungus Phellinus tremulae were established in LRCAF Forest Institute, using the samples from naturally infected Populus tremula trees in Lithuania and following the isolation procedure described by Holmer et al. [37]. 


\subsection{Media}

Plant cultures before and during the experiment were grown on solid Murashige and Skoog (MS) nutrient medium including vitamins, containing $20 \mathrm{~g} \mathrm{~L}^{-1}$ of sucrose and $4 \mathrm{~g} \mathrm{~L}^{-1}$ of gelrite (all the components were purchased from Duchefa Biochemie, Haarlem, The Netherlands). In both the pre-experimental and experimental treatments, the $\mathrm{pH}$ value of the medium for Populus shoot cultures was set at 5.8 before autoclaving for $30 \mathrm{~min}$ at $121^{\circ} \mathrm{C}$. For the experiment, $5.25 \mathrm{~mL}$ of medium was poured into each glass tube $(20 \times 150 \mathrm{~mm})$.

Both species of bacteria were grown on a solid low salt Lysogeny broth (LB) medium (Duchefa Biochemie, The Netherlands). The $\mathrm{pH}$ value of the medium was set at 6.7 before autoclaving.

Fungus P. tremulae was grown on a solid malt medium containing $20 \mathrm{~g} \mathrm{~L}^{-1}$ of maltose, $8 \mathrm{~g} \mathrm{~L}^{-1}$ of yeast extract, $6 \mathrm{~g} \mathrm{~L}^{-1}$ of tryptone, $20 \mathrm{~g} \mathrm{~L}^{-1}$ of glucose and $6 \mathrm{~g} \mathrm{~L}^{-1}$ of gelrite (components purchased from Duchefa Biochemie). The $\mathrm{pH}$ value of the medium was set at 5.8 before autoclaving.

\subsection{Inoculation of Plant Nutrient Medium with Bacteria and Fungi}

For the first-stage inoculation, a day before the transfer of aspen explants, the MS medium in the tubes was spot-inoculated with isolate PP or with isolate L191B using an inoculation needle with $\sim 1.4 \times 10^{6} \mathrm{cfu}$ (colony forming units) of PP or $\sim 6.4 \times 10^{6} \mathrm{cfu}$ of L191B. The bacteria used were taken from bacterial colonies formed on the surface of solid LB medium from overnight cultures.

Bacterial concentrations were determined in a separate experiment using the serial dilution technique.

Fungus $P$. tremulae was used for the second-stage inoculation. The application of fungal inoculate basically followed the method that Seppänen et al. [38] previously used for the wood decay test; a $7 \mathrm{~mm}$ diameter sample from the edges of the mycelial growth was collected using a cork borer, transferred to a tube with the plant medium and placed in the middle, before the transfer of aspen explants.

The survival of both bacteria and fungus were determined visually.

\subsection{Explants in Bacteria/Fungus Inoculated Medium}

Apical segments of in vitro-developed shoots, $10 \mathrm{~mm}$ in length, with leaves removed, were used as explants. The explants were planted in individual tubes with different experimental variants-control (uninoculated medium) and medium inoculated with isolates PP of L191B. In the first culture stage, 30 explants were used in the experiment for each variant for genotype A-37, 34 explants for genotype R-38 and 39 explants for genotypes 174/10 and Wa13. Plants were kept in a growth chamber for six weeks. The temperature in the growth chamber was kept at $25 / 20{ }^{\circ} \mathrm{C}$ under a $16 / 8 \mathrm{~h}$ photoperiod (white light, irradiance $30 \mu \mathrm{mol} \mathrm{m}{ }^{-2} \mathrm{~s}^{-2}$ ).

After six weeks, the morphological parameters (shoot length, largest leaf width) of in vitro-grown plants were recorded and the leaves were harvested for biochemical studies. Then, 10-mm-long apical shoots were transferred to fungus-inoculated tubes for the secondstage trials. Plants were grown for 6 additional weeks under the same conditions as mentioned before. Afterwards, plant vegetative growth parameters (rooting, shoot length and largest leaf width) were measured and leaves were collected for biochemical studies.

The general scheme of the conducted experiments is shown in Table 1. 
Table 1. Scheme of the inoculation experiments, indicating inoculation of plant nutrient medium with different microorganisms (bacteria that were determined to be Paenibacillus sp. and Pseudomonas sp. and fungus, Phellinus tremulae) during two culture stages.

\begin{tabular}{ccc}
\hline Experimental Variant & $\begin{array}{c}\text { First Culture Stage } \\
\text { (Six Weeks) }\end{array}$ & $\begin{array}{c}\text { Second Culture Stage } \\
\text { (Six Weeks) }\end{array}$ \\
\hline Control & - & - \\
$+\mathrm{Pt}$. & - & P. tremulae \\
Paen & Paenibacillus sp. & - \\
Paen $+\mathrm{Pt}$ & Paenibacillus sp. & P. tremulae \\
Pseu & Pseudomonas sp. & - \\
Pseu $+\mathrm{Pt}$ & Pseudomonas sp. & P. tremulae \\
\hline
\end{tabular}

\subsection{Extract Preparation for Secondary Metabolite Analysis}

Fresh leaf (500 mg) samples were stored at $-20{ }^{\circ} \mathrm{C}$ until bioactive substances were analyzed. Before phenolic compound and flavonoid analysis, the samples were homogenized by mortar and pestle. Then, the homogenized material was shaken with $10 \mathrm{~mL}$ of $75 \%$ methanol for $24 \mathrm{~h}$ at $25^{\circ} \mathrm{C}$ using a Kuhner Shaker X electronic shaker (Adolf Kühner AG, Birsfelden, Switzerland) at $150 \mathrm{rpm}$. Afterwards, the extracts were filtered through Whatman no. 1 filter paper, with retention of 5-8 $\mu \mathrm{m}$.

\subsection{Quantification of Total Phenolic Compounds}

The total phenolic content was determined using Folin-Ciocalteu reagent according to Singleton et al. [39]. Leaf extracts $(0.1 \mathrm{~mL})$ were mixed with $0.1 \mathrm{~mL}$ of Folin-Ciocalteu reagent $(2 \mathrm{~N})$ and $2.5 \mathrm{~mL}$ of distilled water $\left(\mathrm{dH}_{2} \mathrm{O}\right)$. After $6 \mathrm{~min}, 0.5 \mathrm{~mL}$ of $20 \%(w / v)$ sodium carbonate was added into the mixture. The mixtures were left for $30 \mathrm{~min}$ at room temperature. The absorbance was measured using a Synergy HT Multi-Mode Microplate Reader (BioTek Instruments, Inc., Bad Friedrichshall, Germany) at $760 \mathrm{~nm}$ against the reagent blank ( $75 \%$ methanol). The phenol content was expressed as chlorogenic acid per gram of fresh weight of leaves ( $\mathrm{mg} \mathrm{CAE} / \mathrm{g}$ ). The standard calibration curve equation was $y=5.5358 x-0.0423\left(R^{2}=0.9975\right)$.

\subsection{Quantification of Total Flavonoid Content}

The flavonoid content in the extracts was determined according to a method described by Dróżdż et al. [40]. The extract solution $(1 \mathrm{~mL})$ was mixed with $0.3 \mathrm{~mL}$ of $5 \%(w / v)$ $\mathrm{NaNO}_{2}$ and, after $5 \mathrm{~min}, 0.5 \mathrm{~mL}$ of $2 \%(w / v) \mathrm{AlCl}_{3}$ was added. After $6 \mathrm{~min}$, the sample was neutralized with $0.5 \mathrm{~mL}$ of $\mathrm{NaOH}(1 \mathrm{M})$. The absorbance of the mixture was recorded at $470 \mathrm{~nm}$ on the Synergy HT Multi-Mode Microplate Reader. The flavonoid content was expressed in milligrams of catechin per gram of fresh weight of leaves (mg CE/g). The standard calibration curve equation was $y=11.616 x+0.0634\left(R^{2}=0.9983\right)$.

\subsection{Quantification of Photosynthesis Pigments}

Fresh leaves $(0.2 \mathrm{~g})$ were ground in acetone (VWR International, Fontenay-sous-Bois, France), then filtered through Whatman no. 1 filter paper, with retention of $5-8 \mu \mathrm{m}$. All pigment analyses were determined using a UV-VIS spectrophotometer 80+ (PG Instruments, Leicestershire, UK) at the following wavelengths: chlorophyll a, $662 \mathrm{~nm}$; chlorophyll b, $644 \mathrm{~nm}$; carotenoids, $440.5 \mathrm{~nm}$. For the calculation of pigment content, the following models were used [41]:

$$
\begin{gathered}
\text { chl } a=9.784 \times D_{662}-0.990 \times D_{644} \frac{c \times V}{P \times 1000} \\
\text { chl } b=21.426 \times D_{644}-4.650 \times D_{662} \frac{c \times V}{P \times 1000} \\
\text { Carotenoids }=4.695 \times D_{440.5}-0.268 \times(\operatorname{chl} a+b) \frac{c \times V}{P \times 1000}
\end{gathered}
$$


where $c=$ pigment content $\left(\mathrm{mg} \mathrm{g}^{-1}\right), V=$ extract volume $(\mathrm{mL})$ and $P=$ fresh leaf material $(\mathrm{g})$.

\subsection{Statistical Data Analysis}

The results presented in this study include the following parameters: rooting, shoot length, leaf width, chlorophyll a/b ratio, carotenoid content, total phenolic content and total flavonoid content. For the comparison of the obtained results, a two-tailed Welch's $t$-test intended to compare samples with possibly unequal variances was performed to calculate the probability that the means of the different variants are equal [42] (Microsoft Excel).

\section{Results}

\subsection{Isolation and Identification}

Isolate PP was isolated from in vitro cultures of hybrid aspen (Populus tremuloides $\times$ P. tremula; 51DF1001) grown in the laboratory of LRCAF Forest Institute, Lithuania. Based on $16 S$ rRNA gene fragment (1496 bp) sequencing, isolate PP was determined to belong to the Paenibacillus genus (Figure 1a). It was genetically close to Paenibacillus tundrae (99.06\% Identity, NR_044525.1). The other bacterium used in the study (L191B) was isolated from the in vitro cultures of Populus hybrids L191 and 174/10 (Populus tremula $\times$ Populus tremuloides), established in the Forest Research Institute, Department of Forestry and Forest Tree Genetics, Poland (Figure 1b). This bacterium was assigned to the genus Pseudomonas (highly homologous with Pseudomonas oryzihabitans (fragment length, 1476 bp; 99.46\% Identity, NR_117269.1)).

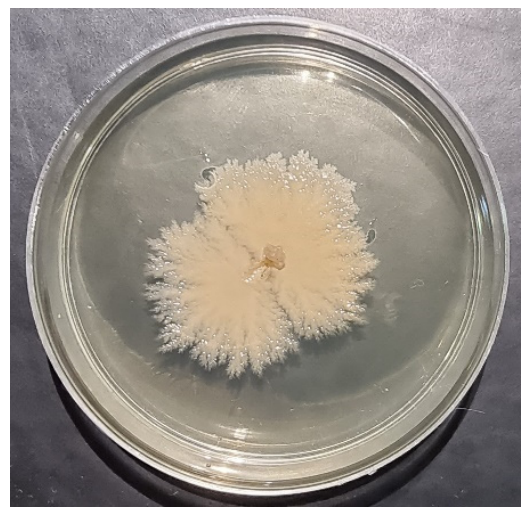

(a)

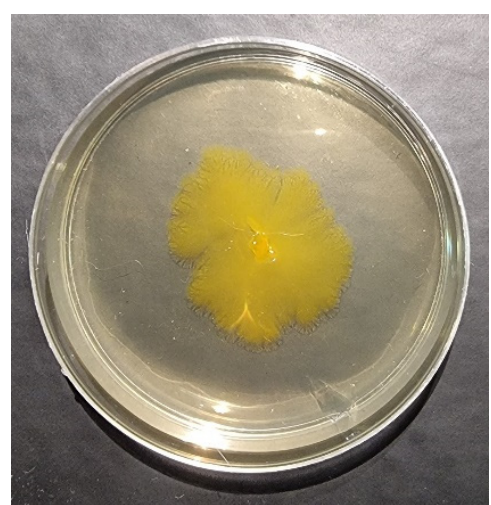

(b)

Figure 1. Morphology of bacterial species used in the experiments (on LB agar after 1 month incubation): (a) isolate PP_Paenibacillus sp.; (b) isolate L191B_Pseudomonas sp.

A phylogenetic tree with both bacteria and their closest genetic matches ( $\geq 97 \%$ Identity) based on sequences from the NCBI database is presented in Figure 2 (MEGA X) [43].

Fungus P. tremulae was isolated from naturally infected Populus tremula trees in Lithuania and cultured on nutrient medium in LRCAF Forest Institute (Figure 3).

\subsection{Effect of the Studied Microorganisms on Rooting of Different Populus Genotypes}

For practical purposes, percentage of rooted explants can be taken as the main indicator of the general viability of Populus shoot cultures. Inoculation of plant nutrient medium with the studied microorganisms resulted in different genotype-specific outcomes, regarding the percentage of rooted explants in the four investigated Populus genotypes (Table 2). 


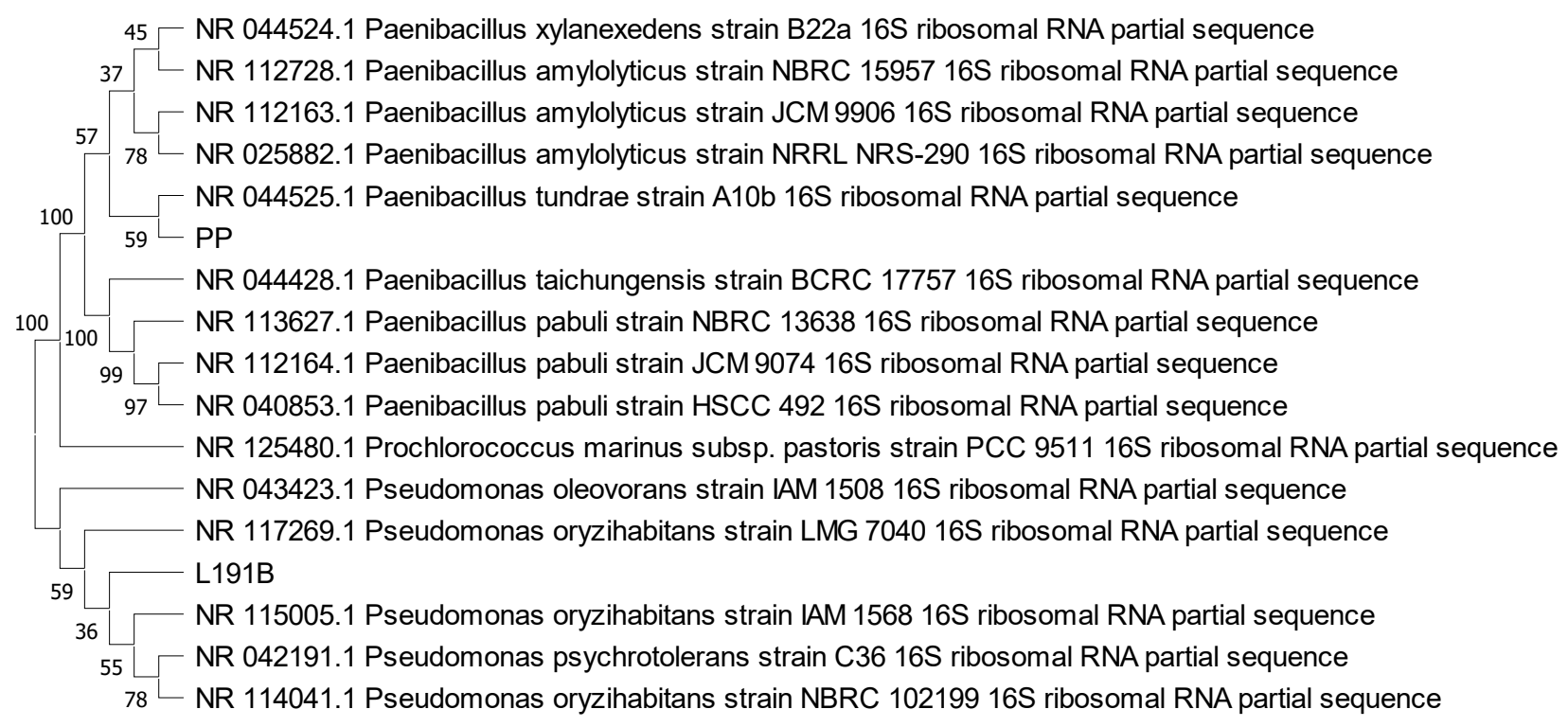

Figure 2. Phylogeny tree based on the neighbor joining method [44] using 16S $r R N A$ gene partial sequences of bacteria from this study (L191B and PP), as well as bacteria that were genetically closest ( $\geq 97 \%$ Identity) and cyanobacteria Prochlorococcus marinus as an outgroup. Branch length is 0.29527974 . Bootstrap values (\%) after 1000 iterations are shown next to the branches [45].

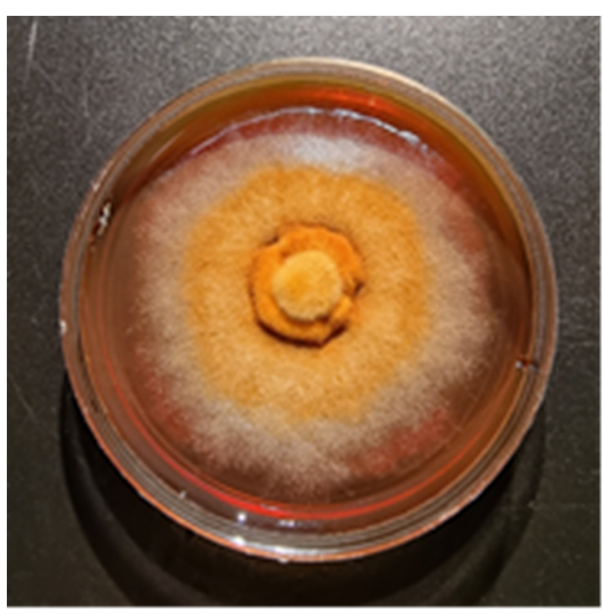

(a)

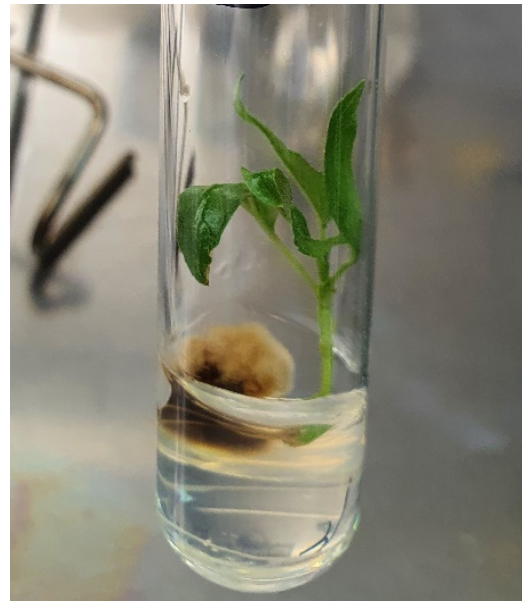

(b)

Figure 3. Fungus P. tremulae: (a) in a pure culture on malt nutrient medium; (b) with a Populus microshoot post inoculation.

The results, given in Table 2, show that, considering the percentage of rooting, only two of the four investigated Populus genotypes were affected positively by some of the studied microorganisms. Interestingly, both of these genotypes were aspens (P. tremula), in contrast to hybrid aspens ( $P$. tremula $\times$ P. tremuloides). Genotype A-37 showed a positive response to the first-stage treatment with bacterium Pseudomonas sp. (average increase of up to $106 \%$ ) and genotype R-38 showed a positive response to the second-stage treatment with fungus Phellinus tremulae (increase of up to 129\%). It can be also noted that the first-stage treatment of R-38 explants with Paenibacillus sp., in contrast to Pseudomonas sp., prevented the positive effect of $P$. tremulae on the rooting of R-38 in the second stage. Meanwhile, both hybrid aspen genotypes (174/10 and Wa13) showed huge drops in rooting ability, if affected by P. tremulae (decrease of 49-100\%). Still, these two genotypes differed from each other in their responses to the first-stage bacterial inoculation. In 174/10, the first stage treatment with Pseudomonas sp. slightly mitigated the negative effect of $P$. tremulae 
(decrease of 49\%). In contrast, Pseudomonas sp. had its own strong negative effect on the culture of genotype Wa13 (decrease of 62\%) and the combination of Pseudomonas sp. and $P$. tremulae resulted in the total absence of rooted explants for this genotype.

Table 2. Percentage of rooted explants in the in vitro cultures of four Populus genotypes after second stage of culturing with different microorganisms. In the first stage, the nutrient medium was inoculated with either Paenibacillus sp. ('Paen') or Pseudomonas sp. ('Pseu') bacteria. For the second stage, explants from each variant were transferred onto fresh medium, either sterile or inoculated with fungus $P$. tremulae ('+ $\left.{ }^{\prime} t^{\prime}\right)$. The control group of explants was cultured on sterile media during both stages.

\begin{tabular}{|c|c|c|c|c|}
\hline \multirow{2}{*}{ Experimental Variant } & \multicolumn{2}{|c|}{ Aspen (P. tremula) } & \multicolumn{2}{|c|}{ Hybrid Aspen (P. tremula $\times P$. tremuloides) } \\
\hline & A-3 $7^{1}$ & $\mathbf{R}-38$ & 174/10 & Wa13 \\
\hline Control & $41.67 \pm 14.86$ & $33.33 \pm 12.6$ & $80 \pm 9.18$ & $87.5 \pm 8.54$ \\
\hline$+\mathrm{Pt}$ & $21.43 \pm 11.38$ & $73.33 \pm 11.82 *$ & $25 \pm 9.93^{* * *}$ & $12.5 \pm 8.54^{* * *}$ \\
\hline Paen & $61.54 \pm 14.04$ & $37.5 \pm 12.5$ & $52.94 \pm 12.48$ & $58.82 \pm 12.3$ \\
\hline Paen + Pt & $28.57 \pm 12.53$ & $31.25 \pm 11.97$ & $23.53 \pm 10.6^{* * *}$ & $16.67 \pm 9.04^{* * *}$ \\
\hline Pseu & $85.71 \pm 9.71 *$ & $50 \pm 12.91$ & $76.47 \pm 10.6$ & $33.33 \pm 11.43^{* * *}$ \\
\hline Pseu + Pt & $57.14 \pm 13.73$ & $76.47 \pm 10.6^{*}$ & $41.18 \pm 12.3$ * & $0^{* * *}$ \\
\hline
\end{tabular}

${ }^{1}$ Statistically significant difference from the control variant (for each genotype separately) are indicated: ${ }^{*} p<0.05 ;{ }^{* * *} p<0.001$.

\subsection{Effect of Bacterial Inoculation on Populus Shoot Growth and Leaf Biochemistry}

Direct effect of nutrient medium inoculation with Paenibacillus sp. or Pseudomonas sp. bacteria on shoot development of different Populus genotypes is shown in Figure 4. In both aspen genotypes (A-37 and R-38), neither average shoot length (Figure 4a), nor leaf width (Figure 4 b) was affected by either of the studied bacteria. A different situation was observed for both hybrid aspen genotypes (174/10 and Wa13), the shoot development parameters of which were significantly decreased by both Paenibacillus sp. and Pseudomonas sp. Of those two genotypes, Wa13 was particularly negatively affected, in terms of average shoot length, by Paenibacillus sp. and, even more so, by Pseudomonas sp. (Figure 4a).

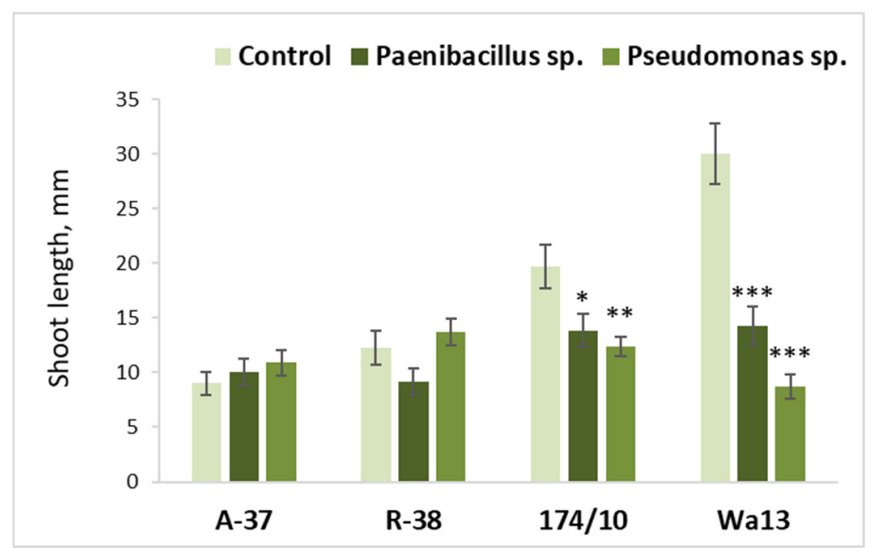

(a)

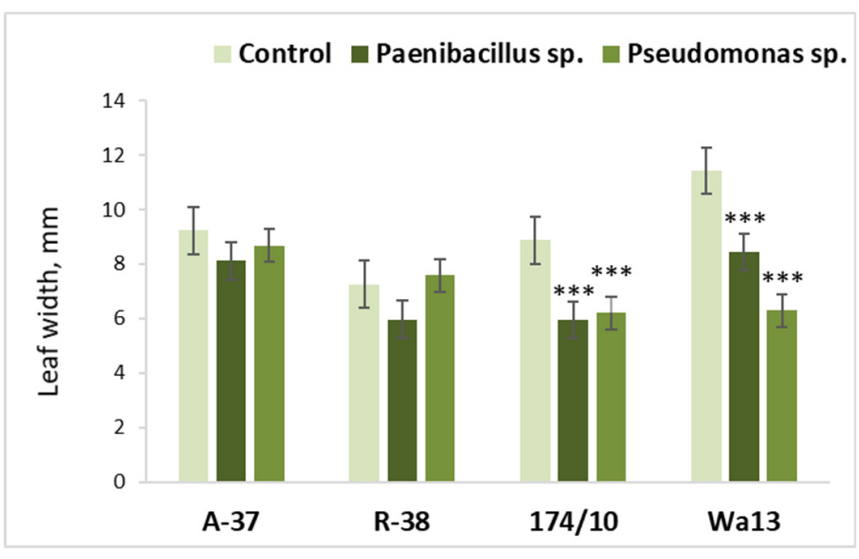

(b)

Figure 4. Average shoot length (a) and leaf width (b) of different Populus genotypes (A-37 and R-38, P. tremula; 174/10 and Wa13, P. tremula $\times$ P. tremuloides), inoculated with Paenibacillus sp. or Pseudomonas sp. bacteria. Statistically significant differences from the bacterium-free control variant are indicated (for each genotype separately): ${ }^{*}<0.05 ;{ }^{* *} p<0.01$; *** $p<0.001$.

Figure 5 illustrates bacterial effects on the pigment contents in Populus leaves. The obtained results show that treatment with bacterium Pseudomonas sp. significantly increased chlorophyll a/b ratio in the A-37 genotype (Figure 5a). Meanwhile, a different situation was observed for both hybrid aspens, whose chlorophyll $a / b$ ratio was significantly decreased in response to this bacterium (Figure 5a). 


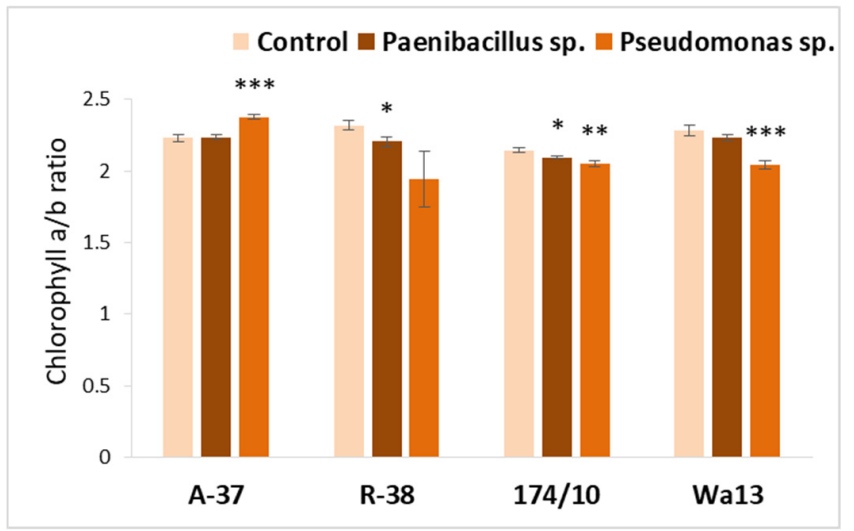

(a)

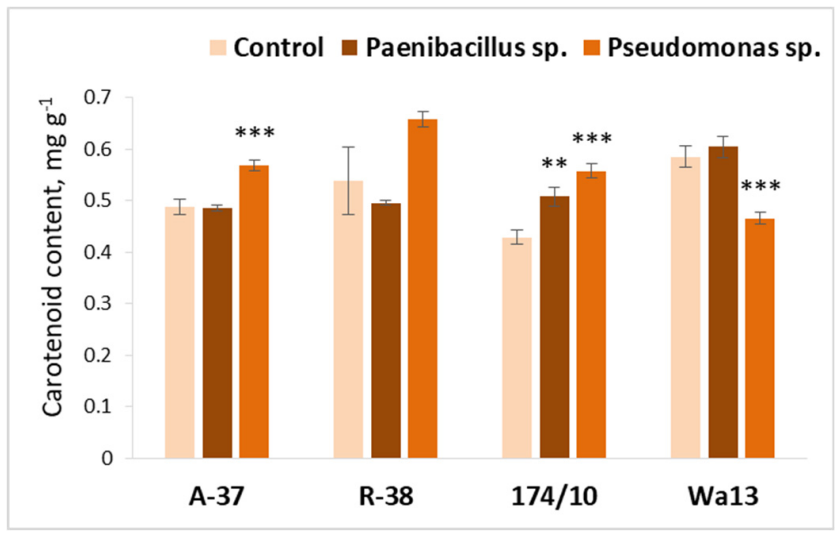

(b)

Figure 5. Average chlorophyll a/b ratio (a) and carotenoid content $(\mathbf{b})$ in the leaves of different Populus genotypes (A-37 and R-38, P. tremula; 174/10 and Wa13, P. tremula $\times$ P. tremuloides), inoculated with Paenibacillus sp. and Pseudomonas sp. bacteria. Statistically significant differences from the bacterium-free control variant are indicated (for each genotype separately): ${ }^{*} p<0.05 ;{ }^{* *} p<0.01 ;{ }^{* * *} p<0.001$.

Similar effects of bacterium Pseudomonas sp., as induced on chlorophyll a/b ratio, were also found the carotenoid content (Figure $5 b$ ) in aspen genotype A-37 and in hybrid aspen genotype Wa13, with the first genotype showing a positive and the latter showing a negative response. Additionally, in respect to carotenoid content, the response of hybrid aspen genotype 174/10 to Pseudomonas sp. was quite similar to that of A-37 and different from Wa13.

Paenibacillus sp. had a negative effect on the chlorophyll a/b ratio in genotypes $\mathrm{R}-38$ and 174/10; however, inoculation with this bacterium caused a significant positive increase in the carotenoid content of genotype 174/10.

The total phenolic content (Figure 6a) highly increased in response to bacterium Pseudomonas sp. in both hybrid aspen genotypes. Meanwhile, the same bacterium decreased the phenolic content in aspen genotype R-38. Paenibacillus sp. had a slight positive effect on total phenol content in genotype A-37.

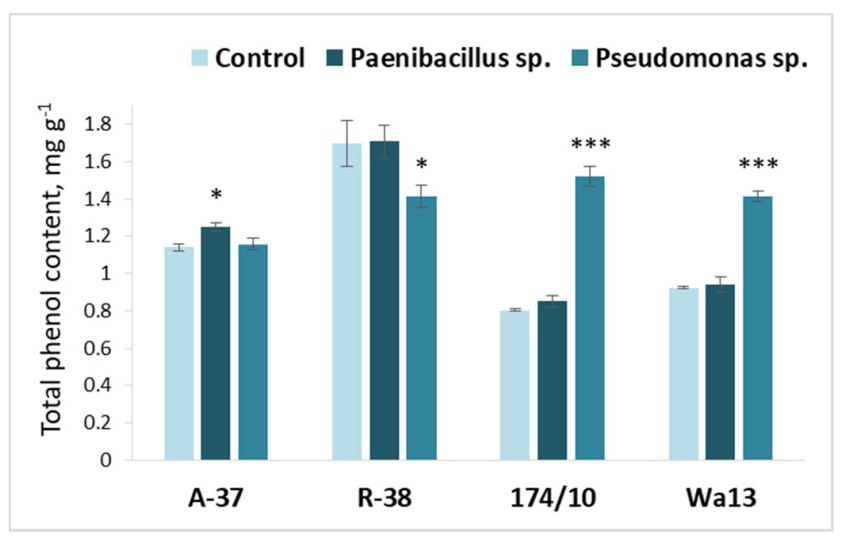

(a)

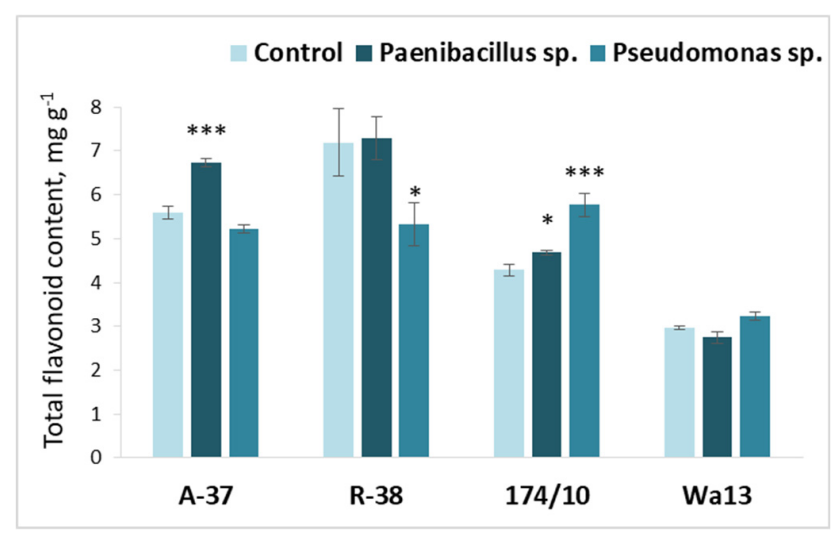

(b)

Figure 6. Average total phenol (a) and flavonoid (b) content in the leaves of different Populus genotypes (A-37 and R-38, P. tremula; 174/10 and Wa13, P. tremula $\times$ P. tremuloides), inoculated with Paenibacillus sp. and Pseudomonas sp. bacteria. Statistically significant differences from the bacterium-free control variant are indicated (for each genotype separately): ${ }^{*} p<0.05 ;{ }^{* * *} p<0.001$.

The results presented in Figure $6 \mathrm{~b}$ reveal obvious differences in total flavonoid content among the studied genotypes. Genotype A-37 showed a positive response to bacterium 
Peanibacilus sp. and genotype R-38 showed negative response to bacterium Pseudomonas sp. Genotype 174/10 showed a positive response to both Paenibacillus sp. and Pseudomonas sp.

3.4. Long-Term Effect of the Studied Bacteria on Populus Shoot Growth and Leaf Biochemistry after Inoculation with Phellinus tremulae

The long-term effect of Paenibacillus sp. or Pseudomonas sp. bacteria on shoot development of different Populus genotypes is shown in Figure 7. These results were obtained after the explants from the bacterium-inoculated nutrient medium were transferred and cultured on either sterile or fungus-inoculated medium (second culture stage). The difference between the two Populus genotype pairs (aspens A-37 and R-38 and hybrid aspens 174/10 and Wa13) in their responses to the studied microorganisms remained distinct during the second experimental stage. Investigated aspen genotypes, in contrast to the hybrids, continued to show a generally positive response; however, the two aspen genotypes still differed from each other in some respects.

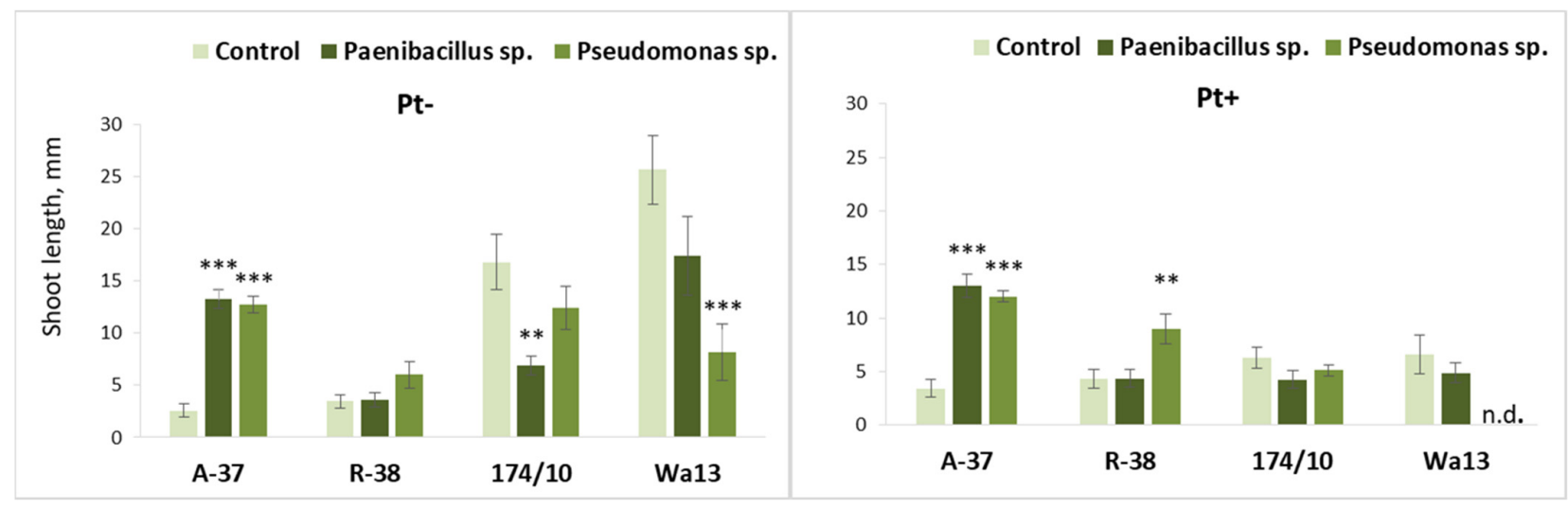

(a)

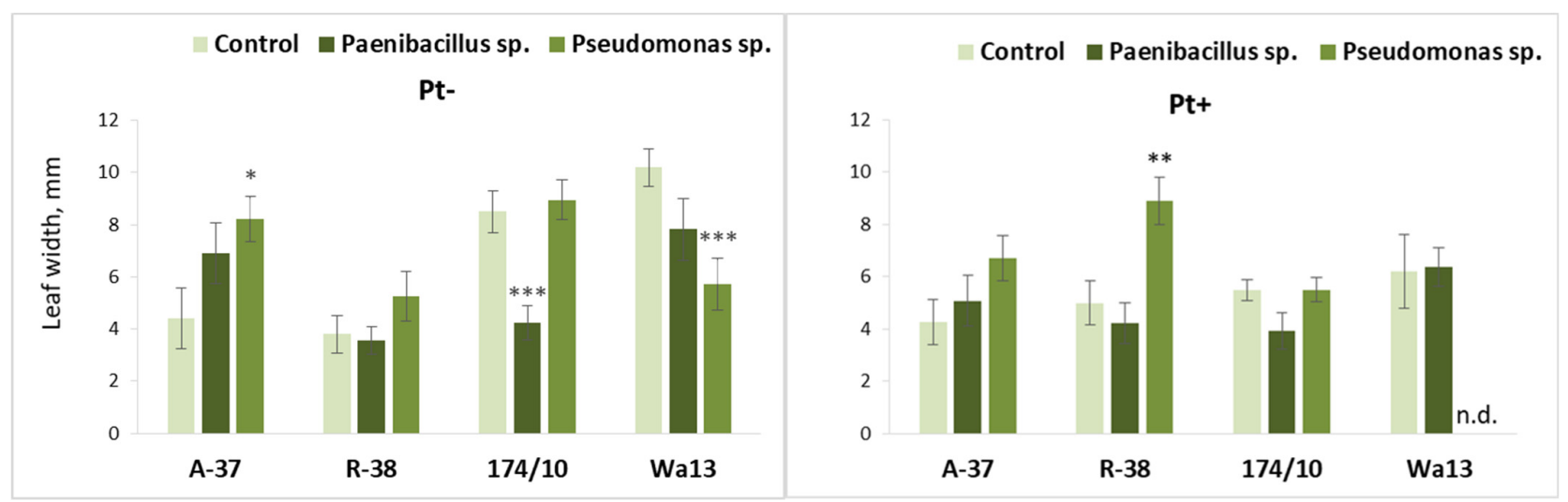

(b)

Figure 7. Average shoot length (a) and leaf width (b) of different Populus genotypes (A-37 and R-38, P. tremula; 174/10 and Wa13, P. tremula $\times$ P. tremuloides), whose explants were first cultured on the nutrient medium inoculated with Paenibacillus sp. or Pseudomonas sp. bacteria, then transferred onto fresh nutrient medium, either sterile ('Pt-') or inoculated with fungus Phellinus tremulae ('Pt+'). Statistically significant differences from the control variant, which was not treated with bacteria during the first culture stage, are indicated (for each genotype separately): ${ }^{*} p<0.05 ;{ }^{* *} p<0.01{ }^{* * *} p<0.001$. 'N.d.' means that, because of decreased explant viability, no reliable data were obtained for a particular variant.

It was found that both Paenibacillus sp. and Pseudomonas sp. caused huge increases in the average shoot length of genotype A-37 during the second culture stage, irrespectively of the P. tremulae inoculation (Figure 7a). Although the bacterial effect on the leaf development of A-37 explants was not so clear, Pseudomonas sp. still caused a significant leaf width 
increase in this genotype on the sterile second-stage medium (Figure $7 \mathrm{~b}$ ). A somewhat different situation was observed in aspen genotype R-38, where bacterial effect on shoot development was not significant, if explants, after bacterial treatment, were transferred onto sterile nutrient medium; however, Pseudomonas sp. approximately doubled both the average shoot length (Figure 7a) and leaf width (Figure 7b) of R-38 explants (108\% and $78 \%$ respectively) on the nutrient medium inoculated with $P$. tremulae. The hybrid aspen genotypes were generally negatively affected by the microorganisms. It can be noted that a significant decrease of average shoot length was caused by Paenibacillus sp. in genotype 174/10 and by Pseudomonas sp. in genotype Wa13 (Figure 7a). The same pattern of bacterial effects on the two hybrid aspen genotypes was observed regarding leaf width (Figure $7 \mathrm{~b}$ ). However, these negative bacterial effects on the hybrid aspens were identifiable only on the sterile second stage medium; meanwhile, on the medium inoculated with P. tremulae, bacterial effects on the shoot development parameters were insignificant because the fungus itself prevented shoot development in both hybrid genotypes.

\subsection{Long-Term Bacterial Inoculation Effect on Populus Leaf Biochemistry after Inoculation with P. tremulae}

The long-term bacterial effects on the photosynthesis pigment (chlorophyll and carotenoid) content in Populus leaves are shown in Figure 8.

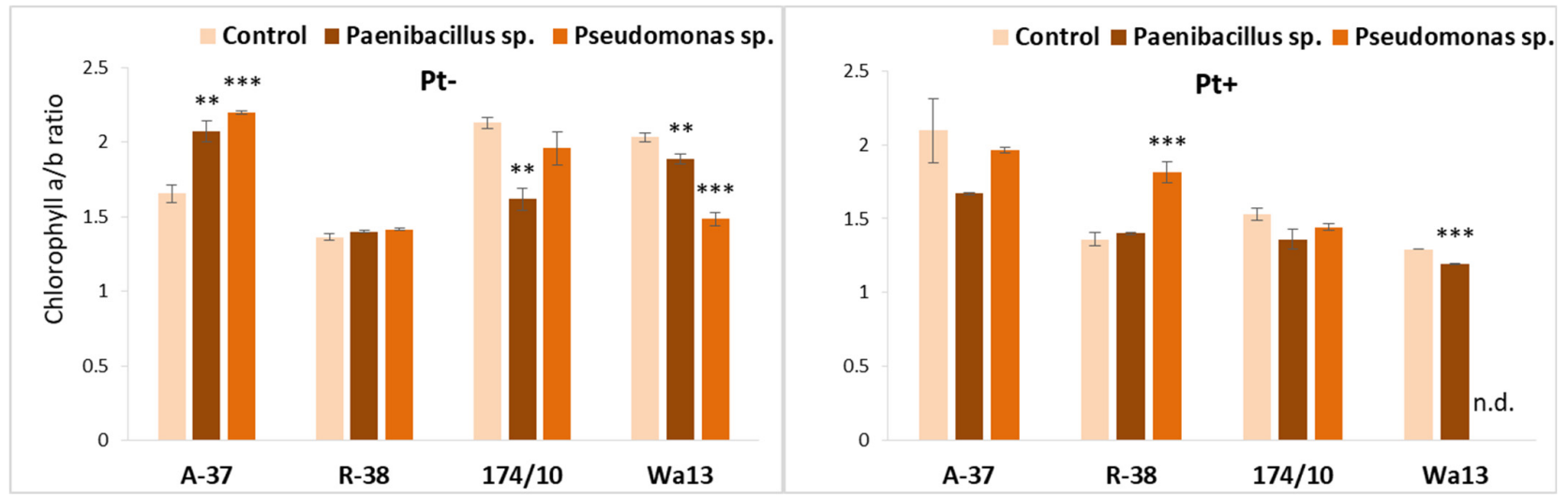

(a)

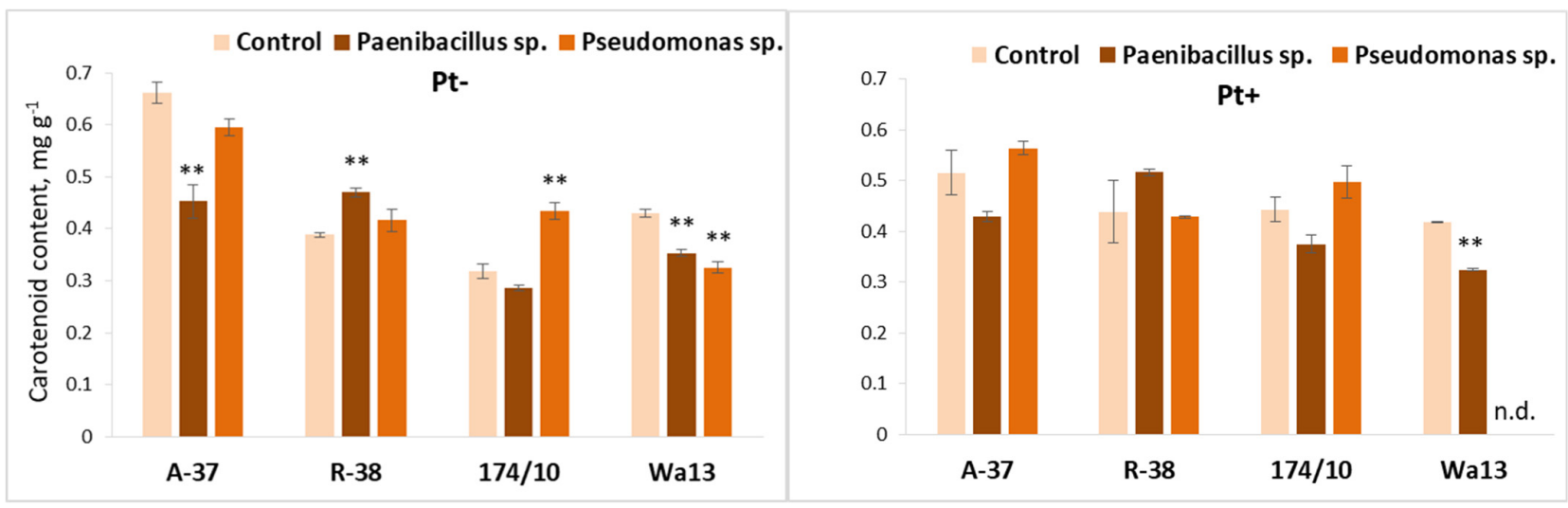

(b)

Figure 8. Average chlorophyll a/b ratio (a) and carotenoid content $(\mathbf{b})$ in the leaves of different Populus genotypes (A-37 and R-38, P. tremula; 174/10 and Wa13, P. tremula $\times$ P. tremuloides), whose explants were first cultured on the nutrient medium inoculated with Paenibacillus sp. or Pseudomonas sp. bacteria, then transferred onto fresh nutrient medium, either sterile ('Pt-') or inoculated with fungus Phellinus tremulae ('Pt+'). Statistically significant differences from the control variant, which was not treated with bacteria during the first culture stage, are indicated (for each genotype separately): ${ }^{* *} p<0.01$; ${ }^{* * *} p<0.001$. 'N.d.' means that, because of decreased explant viability, no reliable data were obtained for a particular variant. 
The chlorophyll $\mathrm{a} / \mathrm{b}$ ratio had the smallest value in genotype $\mathrm{R}-38$ and this parameter remained unresponsive to previous bacterial treatment if a fungus-free medium was used for the second stage (Figure 8a). However, genotype R-38 showed a positive response to the previous Pseudomonas sp. treatment (increase of 33\%), if the second culture stage was conducted on the medium inoculated with $P$. tremulae. Long-term effects on chlorophyll $\mathrm{a} / \mathrm{b}$ ratio of both Paenibacillus sp. and Pseudomonas sp. inoculation were significant in fungus-free aspen genotype A-37 and in hybrid aspen genotype Wa13; the response of A-37 to both bacteria was positive and the response of Wa13 to the same was negative (Figure 8a). Additionally, genotype Wa13 was negatively affected by P. tremulae, if, in the first stage, the explants were inoculated with Paenibacillus sp. Moreover, Paenibacillus sp. had a negative effect on hybrid $174 / 10$ in this respect.

Long-term bacterial effects on carotenoid content were best seen if the medium of the second stage was not inoculated with $P$. tremulae (Figure $8 \mathrm{~b}$ ). It was noted that the long-term effect of Paenibacillus sp. decreased carotenoid content in genotypes A-37 and Wa13, but increased it in genotype R-38; meanwhile, Pseudomonas sp. decreased carotenoid content in genotype Wa13, but increased it in genotype 174/10. Only Paenibacillus sp. had any sort of significant effect on carotenoid content in P. tremulae-inoculated shoots; it was negative in genotype Wa13.

The long-term bacterial effects on the phenol and flavonoid content in Populus leaves are shown in Figure 9.

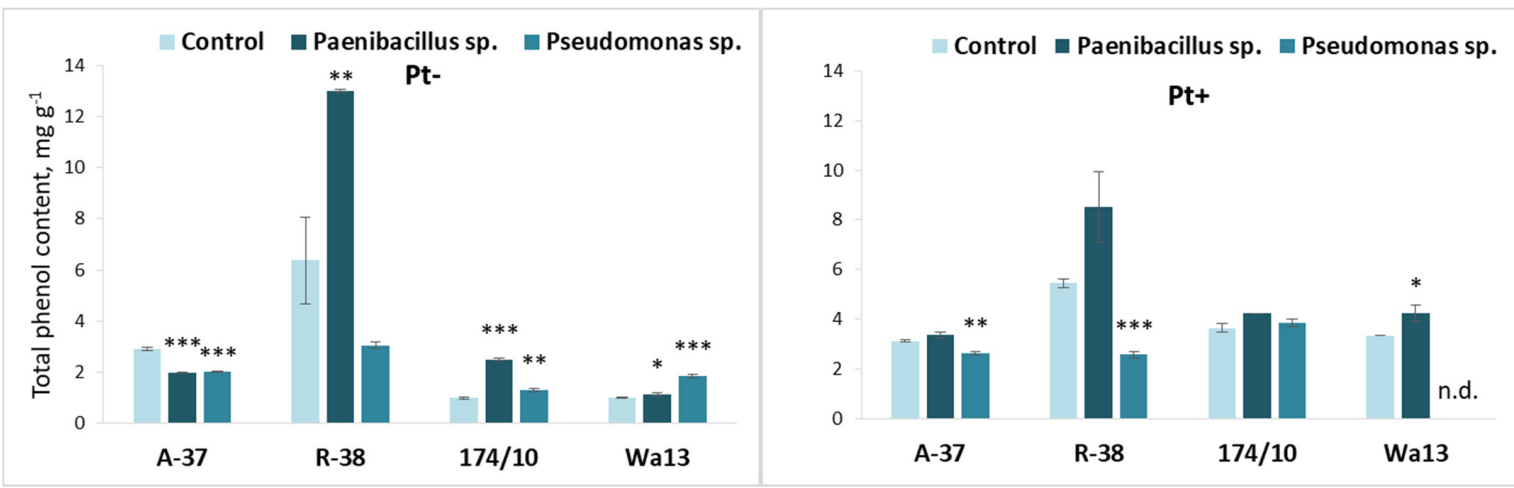

(a)

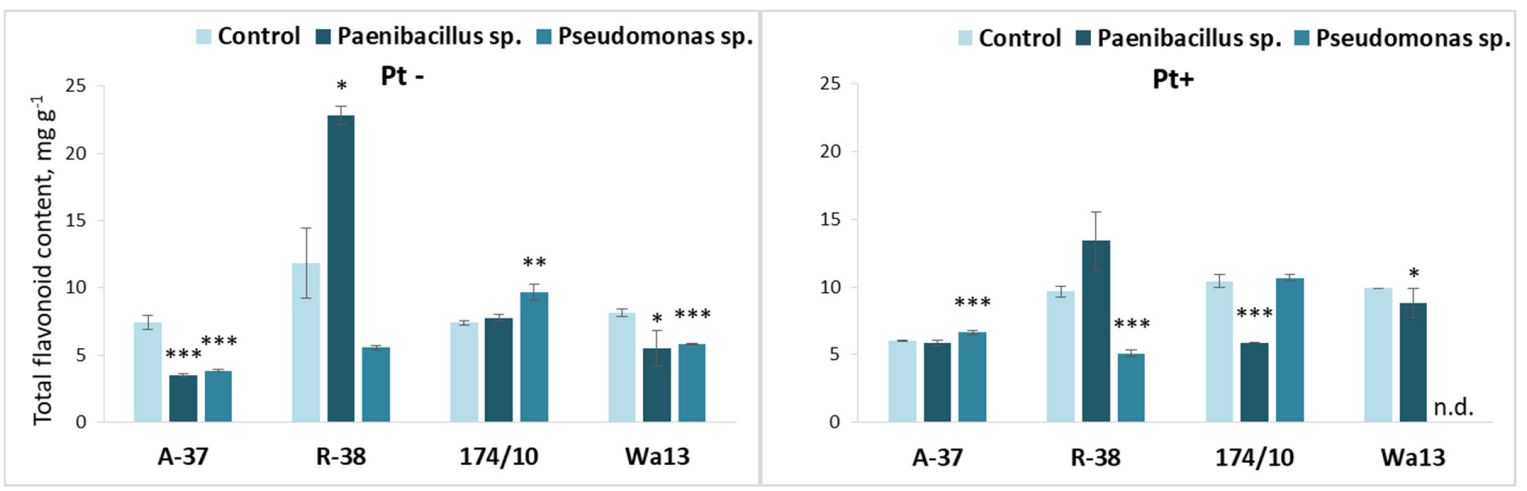

(b)

Figure 9. Average total phenol (a) and flavonoid (b) content in the leaves of different Populus genotypes (A-37 and R-38, P. tremula; 174/10 and Wa13, P. tremula $\times$ P. tremuloides), whose explants were first cultured on the nutrient medium inoculated with Paenibacillus sp. or Pseudomonas sp. bacteria, then transferred onto fresh nutrient medium, either sterile ('Pt-') or inoculated with fungus Phellinus tremulae ('Pt+'). Statistically significant differences from the control variant, which was not treated with bacteria during the first culture stage, are indicated (for each genotype separately): ${ }^{*} p<0.05$; ${ }^{* *} p<0.01 ;{ }^{* *} p<0.001$. 'N.d.' means that, because of decreased explant viability, no reliable data were obtained for a particular variant. 
Particularly interesting results were obtained in the case of aspen genotype R-38; here, the previous treatment with bacterium Peanibacillus sp. led to increased concentrations of stress-resilience indicators, including not only previously described carotenoids (Figure $8 \mathrm{~b}$ ) but also phenolic and flavonoid compounds (increase of $105 \%$ and $93 \%$, respectively) (Figure 9). In both instances, this was observed in fungus-free media.

In fungus-free genotype A-37, total phenol content diminished irrespective of bacteria used; however, similarly, it slightly increased in both hybrid aspen genotypes, irrespective of bacterial inoculation. When inoculated with P. tremulae, Pseudomonas sp. inoculated shoots had lower total phenol content than their respective controls in both aspen genotypes and, in genotype Wa13 previously inoculated with Paenibacillus sp., total phenol content slightly increased.

Both bacteria decreased flavonoid content in genotypes A-37 and Wa13, while Pseudomonas sp. increased it in genotype 174/10 in fungus-free media. Apart from a slight increase in flavonoid content in P. tremulae-inoculated A-37, post Pseudomonas sp. inoculation, Paenibacillus sp. had a significant negative impact on both hybrid aspens, while Pseudomonas sp. had a negative impact on the flavonoid content of R-38.

\section{Discussion}

Different bacteria have been successfully studied in attempts to control various plant pathogens and promote plant growth [46-51]. Both Pseudomonas and Paenibacillus species have been shown to have positive effects on plant growth in previous studies; this is sometimes linked with nitrogen fixation or phytohormone production $[9,48,52]$, etc. In previous studies, Paenibacillus sp. were shown to have a positive effect not only on Populus root-system growth in vitro [9,53], but also on other trees [54-57]. Additionally, both bacterial genera have attracted considerable interest because of their ability to degrade chitin, a key compound found in the walls of fungal cells [46,58].

If compared to Paenibacillus, the data about positive effects of Pseudomonas bacteria on trees are less abundant. Still, it was reported that $P$. fluorescens, isolated from apple trees, induced a positive effect on apple shoots in vitro [59]; $P$. fulva was also shown to have a positive effect on pine seedling growth [51] and P. frederiksbergensis increased Populus euramericana growth in pot trials [60]. The present study showed that bacteria from the genera Paenibacillus and Pseudomonas can be applied for the growth promotion of in vitro-propagated Populus plants, but the particular outcome largely depends on a specific genotype and was temporally variable, with the enhancements becoming statistically significant in the second-stage trials (after 3 months) and not after the first stage (after 6 weeks).

To have a more complete view about the microorganism influence on different Populus genotypes, not only growth parameters but also biochemical changes should be considered. During this study, both tested bacteria were shown to have an impact on chlorophyll $\mathrm{a} / \mathrm{b}$ ratio and carotenoid content, with Pseudomonas sp. having a more notable effect in both respects. However, this too seems to be genotype dependent, as Pseudomonas sp. mostly decreased chlorophyll $\mathrm{a} / \mathrm{b}$ ratio in tested hybrids but had a largely positive effect in one of the $P$. tremula genotypes. Our results indicate that higher chlorophyll $\mathrm{a} / \mathrm{b}$ ratio and carotenoid concentration was related to better rooting in genotype A-37, inoculated with Pseudomonas sp., in the first-stage trials. The same trend was notable in the second stage, whereupon the same genotype produced more chlorophyll in response to the bacterium. Additionally, shoot growth and leaf width of this genotype were positively affected. Otherwise, the effect of both species on carotenoid content was fluctuating.

Carotenoids, as well as chlorophylls, are photosynthesis pigments; however, their functionality in plants is somewhat different [61]. While they both participate in photosynthesis, increases in chlorophyll content are usually linked with the enhancement of plant viability $[57,62]$ (even linking it to bacterial nitrogen fixation or siderophore production in bacteria-plant interaction studies $[63,64])$, while carotenoids are linked with plant stress, antioxidative activity and phytohormone production [65-69]. Several endophytes, both 
fungal and bacterial, have been shown to have an impact on plants' carotenoid $[61,62,65,70]$ and chlorophyll content $[57,62,71]$. Increases in both, ultimately lead to enhancements in net photosynthesis and, thus, carbohydrate synthesis, which, in turn, benefits the plant [65]. Additionally, Benyas et al. noted, that variations in chlorophyll synthesis are closely related to plants' stress response [72].

The present study highlights the effects tested microorganisms may have on Populus SM synthesis. In previous studies, SMs, such as phenols and flavonoids, have been linked with various functions in plants: response to environmental stress, resistance to pathogens and mediation of interactions [14,16-18,73-76]. Flavonoids specifically, are known to be associated with Populus sp. resistance to pathogens [77]. Moreover, plant-associated microorganisms have also been linked with these processes, usually in a regulatory role [16]. It is widely considered that higher production of SMs is associated with enhanced chemical defensive response [18]. This leads to the use of a considerable number of elicitors of biotic and abiotic origin in improving production of the SMs in plant cells $[74,78,79]$.

In our study, Paenibacillus sp. increased total phenol and flavonoid content in genotype A-37 and Pseudomonas sp. increased total phenols in both hybrid aspen during the first stage and both stages, respectively. However, most notably, during the second-stage trials, Paenibacillus sp. increased total phenol content in P. tremula genotype R-38 by $105 \%$. However, this was not linked with a significant growth increase. The same trend was obvious in total flavonoid content, with it being increased by $93 \%$. This variation is not unexpected, as SMs are affected not only by the plant genotype, but also by the physiological and developmental stage and stress levels of said plant $[16,18,73]$.

Cesco et al. indicated that flavonoids can serve to enhance or weaken plant growth by mediating plant-bacterial interactions [80]. Various microbes have been shown to have an effect on plant SM content. For example, the positive effects of bacterium Pseudomonas sp. were described by Nowak [81] and Grover et al. [82]. Authors indicated that bacterium Pseudomonas sp. promoted increased synthesis of phenolic compounds and chlorophylls and promoted the growth of plant roots. Furthermore, it was demonstrated that orchid endophytic fungus could both promote its growth and enhance its flavonoid content [83]. Studies on Paenibacillus spp.'s effects on the SM concentration in plants are scarse, however.

Pathogenic fungus $P$. tremulae had a varied effect on plant growth, pigment content and SM production. Hybrid aspens were especially negatively impacted by the fungus, with loss of viability in genotype Wa13, which, in untreated control, had relatively low concentration of SMs. This correlates with the fact that $P$. tremulae is known to have a more adverse effect on P. tremuloides [34], from which both tested hybrids are descended. Additionally, hybrid aspens responded with decreased viability not only to the fungus, but also to the bacterial treatments. This demonstrates that bacteria may affect different genotypes differently, as is noted in other studies $[9,54,55]$, as well as becoming opportunistic pathogens [84].

Interestingly, despite the pathogenic nature of $P$. tremulae, Eurasian aspen genotype R-38 was positively affected by it in concurrence with previous Pseudomonas sp. inoculation, with increases in rooting, shoot length, leaf width and chlorophyll a/b ratio by $129 \%, 108 \%$, $78 \%$ and $33 \%$, respectively. Moreover, the fungus alone had a positive effect on rooting, up to $120 \%$ in the same genotype. This can be linked with the impact Pseudomonas sp. had on total phenol and flavonoid contents in both P. tremula genotypes; thus, our results indicate that the changes in SM concentration in studied genotypes was potentially related to their antipathogenic response, even though this was not linear.

Previous studies show that Pseudomonas are known to increase plant resistance to stress and pathogens [51,85-87]; however, to our knowledge, no studies on trees or with $P$. tremulae have been conducted thus far, though several older studies demonstrated the biocontrol capabilities of fungi against this pathogen [14,22,23,35].

While, additionally to the present results, other studies have also found that increases in microbe-stimulated plant SM production are linked with growth promotion and pathogen resistance, this link is often complex and hard to interpret, as the relationship 
between plants and their microbiota is a dynamic one-studies have shown that microbes can affect SMs that, in turn, modulate plants' microbiome [16].

\section{Conclusions}

The studied microorganisms, bacteria Paenibacillus sp. and Pseudomonas sp. and fungus Phellinus tremulae, had significant effects on growth parameters, photosynthetic pigment content and secondary metabolite production in four different Populus genotypes, cultured in vitro. However, these effects were variable and clearly genotype-dependent. It was found that the two genotypes (both Populus tremula $\times$ P. tremuloides), whose development in vitro was significantly damaged by Phellinus tremulae, were also characterized by certain responses to the studied bacteria: decreased shoot development in response to both Paenibacillus sp. and Pseudomonas sp. and increased phenol content in response to Pseudomonas sp. In turn, these responses were lacking in the other two tested genotypes (both Populus tremula). Additionally, these genotypes showed in vitro resistance to the fungus and positive, long-term growth responses to bacterial inoculation, even synergistic with the subsequent fungal inoculation. Hence, the studied bacteria were demonstrated as a potential tool both for the detection of fungus-susceptible Populus genotypes and for the improved of in vitro propagation of fungus-resistant genotypes.

Based on the results of these preliminary findings, future studies will be geared towards investigating how varied concentrations of bacteria may affect the plants and P. tremulae. Subsequent ex vitro trials are also to begin.

Author Contributions: Conceptualization, V.S.-Š. and J.Ž.; methodology, V.S.-Š., J.Ž., D.V.; software, G.S., D.V.; formal analysis, V.S.-̌̌., J.Ž. and G.S.; investigation, G.S., D.V.; resources, J.Ž.; data curation, G.S.; writing—original draft preparation, V.S.-̌̌s., J.Ž., G.S., D.V.; writing—review and editing, V.S.-̌̌s., J.Ž., G.S., D.V.; visualization, G.S. and J.Ž.; supervision, V.S.-Š. and J.Ž.; project administration, V.S.-Š. All authors have read and agreed to the published version of the manuscript.

Funding: This research has received funding from European Social Fund (project No 09.3.3-LMT-K712-22-0269) under grant agreement with the Research Council of Lithuania (LMTLT).

Institutional Review Board Statement: Not applicable.

Informed Consent Statement: Not applicable.

Data Availability Statement: Complete study data is available upon request.

Conflicts of Interest: The authors declare no conflict of interest.

\section{References}

1. Ennos, R.A. Resilience of forests to pathogens: An evolutionary ecology perspective. Forestry 2015, 88, 41-52. [CrossRef]

2. Ghelardini, L.; Pepori, A.L.; Luchi, N.; Capretti, P.; Santini, A. Drivers of emerging fungal diseases of forest trees. Ecol. Manag. 2016, 381, 235-246. [CrossRef]

3. Sniezko, R.A. Resistance breeding against nonnative pathogens in forest trees-Current successes in North America. Can. J. Plant Pathol. 2006, 28, 270-279. [CrossRef]

4. Marčiulynas, A.; Sirgedaitė-Šežienè, V.; Žemaitis, P.; Baliuckas, V. The resistance of scots pine (Pinus sylvestris L.) half-sib families to heterobasidion annosum. Forests 2019, 10, 287. [CrossRef]

5. Jia, Q.; Qu, J.; Mu, H.; Sun, H.; Wu, C. Foliar endophytic fungi: Diversity in species and functions in forest ecosystems. Symbiosis 2020, 80, 103-132. [CrossRef]

6. Khare, E.; Mishra, J.; Arora, N.K. Multifaceted interactions between endophytes and plant: Developments and Prospects. Front. Microbiol. 2018, 9, 1-12. [CrossRef] [PubMed]

7. Suman, A.; Yadav, A.N.; Verma, P. Endophytic microbes in crops: Diversity and beneficial impact for sustainable agriculture. In Microbial Inoculants in Sustainable Agricultural Productivity; Singh, D., Singh, H., Prabha, R., Eds.; Springer: New Delhi, India, 2016; Volume 1, pp. 117-143. [CrossRef]

8. Wani, Z.A.; Ashraf, N.; Mohiuddin, T.; Riyaz-Ul-Hassan, S. Plant-endophyte symbiosis, an ecological perspective. Appl. Microbiol. Biotechnol. 2015, 99, 2955-2965. [CrossRef]

9. Vaitiekūnaitè, D.; Kuusienè, S.; Beniušytè, E. Oak (Quercus robur) Associated Endophytic Paenibacillus sp. Promotes Poplar (Populus spp.) Root Growth In Vitro. Microorganisms 2021, 9, 1151. [CrossRef] 
10. Bulgarelli, D.; Schlaeppi, K.; Spaepen, S.; van Themaat, E.V.L.; Schulze-Lefert, P. Structure and Functions of the Bacterial Microbiota of Plants. Annu. Rev. Plant Biol. 2013, 64, 807-838. [CrossRef]

11. Van der Lelie, D.; Taghavi, S.; Monchy, S.; Schwender, J.; Miller, L.; Ferrieri, R.; Rogers, A.; Wu, X.; Zhu, W.; Weyens, N.; et al. Poplar and its bacterial endophytes: Coexistence and harmony. CRC Crit. Rev. Plant Sci. 2009, 28, 346-358. [CrossRef]

12. Pirttilä, A.M.; Mohammad Parast Tabas, H.; Baruah, N.; Koskimäki, J.J. Biofertilizers and Biocontrol Agents for Agriculture: How to Identify and Develop New Potent Microbial Strains and Traits. Microorganisms 2021, 9, 817. [CrossRef]

13. Terhonen, E.; Blumenstein, K.; Kovalchuk, A.; Asiegbu, F.O. Forest tree microbiomes and associated fungal endophytes: Functional roles and impact on forest health. Forests 2019, 10, 42. [CrossRef]

14. Witzell, J.; Martín, J.A. Phenolic metabolites in the resistance of northern forest trees to pathogens-Past experiences and future prospects. Can. J. Res. 2008, 38, 2711-2727. [CrossRef]

15. Li, Y.; Zhang, W.; Sun, N.; Wang, X.; Feng, Y.; Zhang, X. Identification and functional verification of differences in phenolic compounds between resistant and susceptible Populus species. Phytopathology 2020, 110, 805-812. [CrossRef]

16. Pang, Z.; Chen, J.; Wang, T.; Gao, C.; Li, Z.; Guo, L. Linking Plant Secondary Metabolites and Plant Microbiomes: A Review. Front. Plant Sci. 2021, 12, 621276. [CrossRef]

17. Zaynab, M.; Fatima, M.; Abbas, S.; Sharif, Y.; Umair, M.; Zafar, M.H.; Bahadar, K. Role of secondary metabolites in plant defense against pathogens. Microb. Pathog. 2018, 124, 198-202. [CrossRef] [PubMed]

18. Isah, T. Stress and defense responses in plant secondary metabolites production. Biol. Res. 2019, 52, 39. [CrossRef]

19. Sirgedaitė-Šèžienė, V.; Mildažienė, V.; Žemaitis, P.; Ivankov, A.; Koga, K.; Shiratani, M.; Baliuckas, V. Long-term response of Norway spruce to seed treatment with cold plasma: Dependence of the effects on the genotype. Plasma Process. Polym. 2021, 18, 2000159. [CrossRef]

20. Maggini, V.; De Leo, M.; Mengoni, A.; Gallo, E.R.; Miceli, E.; Reidel, R.V.B.; Biffi, S.; Pistelli, L.; Fani, R.; Firenzuoli, F.; et al. Plant-endophytes interaction influences the secondary metabolism in Echinacea purpurea (L.) Moench: An in vitro model. Sci. Rep. 2017, 7, 16924. [CrossRef]

21. Hardoim, P.R.; van Overbeek, L.S.; Berg, G.; Pirttilä, A.M.; Compant, S.; Campisano, A.; Döring, M.; Sessitsch, A. The Hidden World within Plants: Ecological and Evolutionary Considerations for Defining Functioning of Microbial Endophytes. Microbiol. Mol. Biol. Rev. 2015, 79, 293-320. [CrossRef] [PubMed]

22. Chakravarty, P.; Hiratsuka, Y. Antagonism of two decay fungi, Peniophora polygonia and Phellinus tremulae associated with Populus tremuloides. Eur. J. Pathol. 1992, 22, 354-361. [CrossRef]

23. Hutchison, L.J.; Chakravarty, P.; Kawchuk, L.M.; Hiratsuka, Y. Phoma etheridgei sp.nov. from black galls and cankers of trembling aspen (Populus tremuloides) and its potential role as a bioprotectant against the aspen decay pathogen Phellinus tremulae. Can. J. Bot. 1994, 72, 1424-1431. [CrossRef]

24. Mallett, K.I.; Myrholm, C.L. The mating system of Phellinus tremulae. Mycologia 1995, 87, 597-603. [CrossRef]

25. Yu, Q.; Tigerstedt, P.M.A.; Haapanen, M. Growth and phenology hybrid aspen clones (Populus tremula L. $\times$ Populus tremuloides Michx.). Silva. Fenn. 2001, 35, 15-25. [CrossRef]

26. Watanabe, S.; Kojima, K.; Ide, Y.; Sasaki, S. Effects of saline and osmotic stress on proline and sugar accumulation in Populus euphratica in vitro. Plant Cell Tissue Organ. Cult. 2000, 63, 199-206. [CrossRef]

27. Tullus, A.; Tullus, H.; Vares, A.; Kanal, A. Early growth of hybrid aspen (Populus $\times$ wettsteinii Hämet-Ahti) plantations on former agricultural lands in Estonia. Ecol. Manag. 2007, 245, 118-129. [CrossRef]

28. Gottel, N.R.; Castro, H.F.; Kerley, M.; Yang, Z.; Pelletier, D.A.; Podar, M.; Karpinets, T.; Uberbacher, E.; Tuskan, G.A.; Vilgalys, R.; et al. Distinct Microbial Communities within the Endosphere and Rhizosphere of Populus deltoides Roots across Contrasting Soil Types. Appl. Env. Microbiol. 2011, 77, 5934-5944. [CrossRef] [PubMed]

29. Cregger, M.A.; Carper, D.L.; Christel, S.; Doktycz, M.J.; Labbé, J.; Michener, J.K.; Dove, N.C.; Johnston, E.R.; Moore, J.A.M.; Vélez, J.M.; et al. Plant-Microbe Interactions: From Genes to Ecosystems Using Populus as a Model System. Phytobiomes J. 2021, 5, 29-38. [CrossRef]

30. Cregger, M.A.; Veach, A.M.; Yang, Z.K.; Crouch, M.J.; Vilgalys, R.; Tuskan, G.A.; Schadt, C.W. The Populus holobiont: Dissecting the effects of plant niches and genotype on the microbiome. Microbiome 2018, 6, 1-14. [CrossRef]

31. Duplessis, S.; Major, I.; Martin, F.; Séguin, A. Poplar and pathogen interactions: Insights from Populus genome-wide analyses of resistance and defense gene families and gene expression profiling. CRC Crit. Rev. Plant Sci. 2009, 28, 309-334. [CrossRef]

32. State Forest Service of Lithuania. Lietuvos Valstybinių Mišku Sanitarinės Būklès Apžvalga, 2020m; State Forest Service of Lithuania: Kaunas, Lithuania, 2021.

33. Ayer, W.A.; Cruz, E.R. The Tremulanes, a New Group of Sesquiterpenes from the Aspen Rotting Fungus Phellinus tremulae. J. Org. Chem. 1993, 58, 7529-7534. [CrossRef]

34. Brazee, N.J. Phylogenetic relationships among species of Phellinus sensu stricto, cause of white trunk rot of hardwoods, from Northern North America. Forests 2015, 6, 4191-4211. [CrossRef]

35. Trifonov, L.S.; Chakravarty, P.; Hiratsuka, Y.; Ayer, W.A. Antifungal activity of metabolites of Peniophora polygonia against the aspen decay fungus Phellinus tremulae. Eur. J. Pathol. 1992, 22, 441-448. [CrossRef]

36. Verbylaitè, R.; Baliuckas, V.; Kuusienè, S. European aspen (Populus tremula L.) genetic diversity assessed by molecular methods correlation with P. tremulae infection incidence. Biologija 2015, 61, 130-144. [CrossRef] 
37. Holmer, L.; Nitare, L. Population structure and decay pattern of Phellinus tremulae in Populus tremula as determined by somatic incompatibility. Can. J. Bot. 2011, 72, 1391-1396. [CrossRef]

38. Seppänen, S.K.; Syrjälä, L.; Weissenberg, K.; Teeri, T.H.; Paajanen, L.; Pappinen, A. Antifungal activity of stilbenes in in vitro bioassays and in transgenic Populus expressing a gene encoding pinosylvin synthase. Plant Cell Rep. 2004, 22, 584-593. [CrossRef] [PubMed]

39. Singleton, V.L.; Orthhofer, R.; Lamuela-Raventos, R.M. Analysis of Total Phenols and Other Oxidation Substrates and Antioxidants by Means of Folin-Ciocalteu Reagent. Methods Enzym. 1974, 299, 152-178. [CrossRef]

40. Drózdz, P.; Šèžienè, V.; Wójcik, J.; Pyrzyńska, K. Evaluation of bioactive compounds, minerals and antioxidant activity of lingonberry (Vaccinium vitis-idaea L.) Fruits. Molecules 2018, 23, 53. [CrossRef]

41. Wettstein, D. Chlorophyll-letale und der submikroskopische Formwechsel der Plastiden. Exp. Cell Res. 1957, 12, 427-506. [CrossRef]

42. Welch, B.L. The Generalization of 'Students' Problem when Several Different Population Variances are Involved. Biometrika 1947, 34, 28. [CrossRef] [PubMed]

43. Kumar, S.; Stecher, G.; Li, M.; Knyaz, C.; Tamura, K. MEGA X: Molecular Evolutionary Genetics Analysis across computing platforms. Mol. Biol. Evol. 2018, 35, 1547-1549. [CrossRef]

44. Saitou, N.; Nei, M. The neighbor-joining method: A new method for reconstructing phylogenetic trees. Mol. Biol. Evol. 1987, 4, 406-425. [PubMed]

45. Felsenstein, J. Confidence limits on phylogenies: An approach using the bootstrap. Evolution 1985, 39, 783-791. [CrossRef]

46. Miliute, I.; Buzaite, O.; Gelvonauskiene, D.; Sasnauskas, A.; Stanys, V.; Baniulis, D. Plant growth promoting and antagonistic properties of endophytic bacteria isolated from domestic apple Inga. Zemdirbyste Agric. 2016, 103, 77-82. [CrossRef]

47. Von Der Weid, I.; Artursson, V.; Seldin, L.; Jansson, J.K. Antifungal and root surface colonization properties of GFP-tagged Paenibacillus brasilensis PB177. World J. Microbiol. Biotechnol. 2005, 21, 1591-1597. [CrossRef]

48. Grady, E.N.; MacDonald, J.; Liu, L.; Richman, A.; Yuan, Z.C. Current knowledge and perspectives of Paenibacillus: A review. Microb. Cell Fact. 2016, 15, 1-18. [CrossRef] [PubMed]

49. Govindasamy, V.; Senthilkumar, M.; Magheshwaran, V.; Kumar, U.; Bose, P.; Sharma, V.; Annapurna, K. Bacillus and Paenibacillus spp.: Potential PGPR for Sustainable Agriculture. In Plant Growth and Health Promoting Bacteria; Springer: Berlin/Heidelberg, Germany, 2010; Volume 18, pp. 333-356. [CrossRef]

50. Ulrich, K.; Becker, R.; Behrendt, U.; Kube, M.; Ulrich, A. A Comparative Analysis of Ash Leaf-Colonizing Bacterial Communities Identifies Putative Antagonists of Hymenoscyphus fraxineus. Front. Microbiol. 2020, 11, 966. [CrossRef]

51. Pokojska-Burdziej, A.; Strzelczyk, E.; Dahm, H.; Li, C.Y. Effect of Endophytic Bacterium Pseudomonas Fulva on Growth of Pine Seedlings (Pinus Sylvestris), Formation of Mycorrhizae and Protection Against Pathogens. Phytopathol. Pol. 2004,32 , 33-47.

52. Scherling, C.; Ulrich, K.; Ewald, D.; Weckwerth, W. A metabolic signature of the beneficial interaction of the endophyte Paenibacillus sp. isolate and in vitro-grown poplar plants revealed by metabolomics. Mol. Plant-Microbe Interact. 2009, 22, 1032-1037. [CrossRef]

53. Ulrich, K.; Stauberm, T.; Ewald, D. Paenibacillus-A predominant endophytic bacterium colonising tissue cultures of woody plants. Plant Cell Tissue Organ Cult. 2008, 93, 347-351. [CrossRef]

54. Bal, A.; Chanway, C.P. $15 \mathrm{~N}$ foliar dilution of western red cedar in response to seed inoculation with diazotrophic Paenibacillus polymyxa. Biol. Fertil. Soils 2012, 48, 967-971. [CrossRef]

55. Bal, A.; Chanway, C.P. Evidence of nitrogen fixation in lodgepole pine inoculated with diazotrophic Paenibacillus polymyxa. Botany 2012, 90, 891-896. [CrossRef]

56. Tang, Q.; Puri, A.; Padda, K.P.; Chanway, C.P. Biological nitrogen fixation and plant growth promotion of lodgepole pine by an endophytic diazotroph Paenibacillus polymyxa and its GFP-tagged derivative. Botany 2017, 95, 611-619. [CrossRef]

57. Kumari, M.; Thakur, I.S. Biochemical and proteomic characterization of Paenibacillus sp. ISTP10 for its role in plant growth promotion and in rhizostabilization of cadmium. Bioresour. Technol. Rep. 2018, 3, 59-66. [CrossRef]

58. Afzal, I.; Shinwari, Z.K.; Iqrar, I. Selective isolation and characterization of agriculturally beneficial endophytic bacteria from wild hemp using canola. Pak. J. Bot. 2015, 47, 1999-2008.

59. Tamošiūnè, I.; Stanienè, G.; Haimi, P.; Stanys, V.; Rugienius, R.; Baniulis, D. Endophytic Bacillus and Pseudomonas spp. Modulate Apple Shoot Growth, Cellular Redox Balance, and Protein Expression Under in vitro Conditions. Front. Plant Sci. $2018,9,889$. [CrossRef]

60. Zeng, Q.; Wu, X.; Wen, X. Identification and characterization of the rhizosphere phosphate-solubilizing bacterium Pseudomonas frederiksbergensis JW-SD2, and its plant growth-promoting effects on poplar seedlings. Ann. Microbiol. 2016, 66, 1343-1354. [CrossRef]

61. Jang, J.H.; Kim, S.H.; Khaine, I.; Kwak, M.J.; Lee, H.K.; Lee, T.Y.; Lee, W.Y.; Woo, S.Y. Physiological changes and growth promotion induced in poplar seedlings by the plant growth-promoting rhizobacteria Bacillus subtilis JS. Photosynthetica 2018, 56, 1188-1203. [CrossRef]

62. Ikram, M.; Ali, N.; Jan, G.; Jan, F.G.; Rahman, I.U.; Iqbal, A.; Hamayun, M. IAA producing fungal endophyte Penicillium roqueforti Thom., enhances stress tolerance and nutrients uptake in wheat plants grown on heavy metal contaminated soils. PLOS ONE 2018, 13, 1-22. [CrossRef] 
63. Iniguez, A.L.; Dong, Y.; Triplett, E.W. Nitrogen fixation in wheat provided by Klebsiella pneumoniae 342. Mol. Plant-Microbe Interact. 2004, 17, 1078-1085. [CrossRef] [PubMed]

64. Liu, D.; Yang, Q.; Ge, K.; Hu, X.; Qi, G.; Du, B.; Liu, K.; Ding, Y. Promotion of iron nutrition and growth on peanut by Paenibacillus illinoisensis and Bacillus sp. strains in calcareous soil. Braz. J. Microbiol. 2017, 48, 656-670. [CrossRef]

65. Kumar, V.; Kumar, M.; Sharma, S.; Prasad, R. Probiotics and Plant Health; Springer: Singapore, 2017. [CrossRef]

66. Havaux, M. Carotenoid oxidation products as stress signals in plants. Plant J. 2014, 79, 597-606. [CrossRef]

67. Cazzonelli, C.I. Carotenoids in nature: Insights from plants and beyond. Funct. Plant Biol. 2011, 38, 833-847. [CrossRef]

68. DellaPenna, D. Carotenoid synthesis and function in plants: Insights from mutant studies in Arabidopsis. Pure Appl. Chem. 1999, 71, 2205-2212. [CrossRef]

69. Nisar, N.; Li, L.; Lu, S.; Khin, N.C.; Pogson, B.J. Carotenoid metabolism in plants. Mol. Plant 2015, 8, 68-82. [CrossRef] [PubMed]

70. Wani, Z.A.; Kumar, A.; Sultan, P.; Bindu, K.; Riyaz-Ul-Hassan, S.; Ashraf, N. Mortierella alpina CS10E4, an oleaginous fungal endophyte of Crocus sativus L. enhances apocarotenoid biosynthesis and stress tolerance in the host plant. Sci. Rep. 2017, 7, 1-11. [CrossRef] [PubMed]

71. Lubna, A.S.; Hamayun, M.; Gul, H.; Lee, I.J.; Hussain, A. Aspergillus Niger CSR3 regulates plant endogenous hormones and secondary metabolites by producing gibberellins and indoleacetic acid. J. Plant Interact. 2018, 13, 100-111. [CrossRef]

72. Benyas, E.; Hassanpouraghdam, M.B.; Zehtab Salmasi, S. Khatamian Oskooei OS. Allelopathic effects of Xanthium strumarium L. Shoot aqueous extract on germination, seedling growth and chlorophyll content of lentil (Lens culinaris Medic.). Rom. Biotechnol. Lett. 2010, 15, 5223-5228.

73. Górniak, I.; Bartoszewski, R.; Króliczewski, J. Comprehensive Review of Antimicrobial Activities of Plant Flavonoids. Phytochem. Rev. 2019, 8, 241-272. [CrossRef]

74. Selmar, D.; Kleinwächter, M. Stress enhances the synthesis of secondary plant products: The impact of stress-related overreduction on the accumulation of natural products. Plant Cell Physiol. 2013, 54, 817-826. [CrossRef]

75. Kim, Y.; Choi, Y.; Sano, H. Plant vaccination: Stimulation of defense system by caffeine production in planta. Plant Signal. Behav. 2010, 5, 489-493. [CrossRef]

76. Hartmann, T. Plant-derived secondary metabolites as defensive chemicals in herbivorous insects: A case study in chemical ecology. Planta 2004, 219, 1-4. [CrossRef]

77. Bai, Q.; Duan, B.; Ma, J.; Fen, Y.; Sun, S.; Long, Q.; Lv, J.; Wan, D. Coexpression of PalbHLH1 and PalMYB90 Genes from Populus alba Enhances Pathogen Resistance in Poplar by Increasing the Flavonoid Content. Front. Plant Sci. 2020, 10, 1-14. [CrossRef] [PubMed]

78. Zhao, J.; Davis, L.C.; Verpoorte, R. Elicitor signal transduction leading to production of plant secondary metabolites. Biotechnol. Adv. 2005, 23, 283-333. [CrossRef] [PubMed]

79. Goyal, S.; Lambert, C.; Cluzet, S.; Merillon, J.M.; Ramawat, K.G. Secondary metabolites and plant defence. In Plant Defence: Biological Control; Springer: Berlin/Heidelberg, Germany, 2012; pp. 109-130. [CrossRef]

80. Cesco, S.; Mimmo, T.; Tonon, G.; Tomasi, N.; Pinton, R.; Terzano, R.; Neumann, G.; Weisskopf, L.; Renella, G.; Landi, L.; et al. Plant-borne flavonoids released into the rhizosphere: Impact on soil bio-activities related to plant nutrition. A review. Biol. Fertil. Soils 2012, 48, 123-149. [CrossRef]

81. Nowak, J. Benefits of in vitro "biotization" of plant tissue cultures with microbial inoculants. Vitr. Cell Dev. Biol.-Plant 1998, 34, 122-130. [CrossRef]

82. Grover, M.; Ali, S.Z.; Sandhya, V.; Rasul, A.; Venkateswarlu, B. Role of microorganisms in adaptation of agriculture crops to abiotic stresses. World J. Microbiol. Biotechnol. 2011, 27, 1231-1240. [CrossRef]

83. Zhang, F.S.; Lv, Y.L.; Zhao, Y.; Guo, S.X. Promoting role of an endophyte on the growth and contents of kinsenosides and flavonoids of Anoectochilus formosanus Hayata, a rare and threatened medicinal Orchidaceae plant. J. Zhejiang Univ. Sci. B 2013, 14, 785-792. [CrossRef] [PubMed]

84. Schulz, B.; Boyle, C. What are Endophytes? In Microbial Root Endophytes Soil Biology; Springer: Berlin/Heidelberg, Germany, 2006; Volume 9, pp. 1-14. [CrossRef]

85. Santoyo, G.; del Orozco-Mosqueda, M.C.; Govindappa, M. Mechanisms of biocontrol and plant growth-promoting activity in soil bacterial species of Bacillus and Pseudomonas: A review. Biocontrol Sci. Technol. 2012, 22, 855-872. [CrossRef]

86. Khaskheli, M.A.; Wu, L.; Chen, G.; Chen, L.; Hussain, S.; Song, D.; Liu, S.; Feng, G. Isolation and characterization of root-associated bacterial endophytes and their biocontrol potential against major fungal phytopathogens of rice (Oryza sativa L.). Pathogens 2020, 9, 172. [CrossRef]

87. Tiwari, S.; Lata, C.; Chauhan, P.S.; Nautiyal, C.S. Pseudomonas putida attunes morphophysiological, biochemical and molecular responses in Cicer arietinum L. during drought stress and recovery. Plant Physiol. Biochem. 2016, 9, 108-117. [CrossRef] [PubMed] 